\title{
CHRONOLOGIA POWSTAWANIA PREBEND W KAPITULE KIELECKIEJ
}

Kapituła kielecka według przekazów źródłowych miała powstać w 1171 r. zinicjatywy biskupa Gedki. Zdaniem Jana Długosza od chwili swego powstania miała liczyć dziesięciu członków. Taki, tj. dziesięcioosobowy, skład kapituły znany jest dopiero z dużo późniejszych przekazów, jednak nawet one pozwalają zakwestionować informację Jana Długosza o utworzeniu wszystkich prebend już w roku $1171^{1}$. W tej sytuacji ukazanie etapów tworzenia kapituły kieleckiej wymaga sięgnięcia do istniejącej bazy źródłowej.

Próby odtworzenia etapów formowania się kapituły kieleckiej podjęli się jak do tej pory J. Szymański² oraz - na marginesie innych rozważań - S. Trawkow$\mathrm{ski}^{3}$.

* Leszek Poniewozik - dr historii, adiunkt w Instytucie Historii Uniwersytetu Rzeszowskiego.

${ }^{1} 10$ prałatów i kanoników kieleckich po raz pierwszy wymienia spis dziesięciny papieskiej $\mathrm{z}$ roku 1350/1351, przy czym w wykazie tym nie podano nazw kanonii utworzonych od fundum patrz Acta Camerae Apostolicae [dalej ACA], t. 2, wyd. J. Ptaśnik, w: Monumenta Poloniae Vaticana, Kraków 1913, s. 369-370. Później 10 prałatów i kanoników kieleckich wymienia Liber beneficiorum Jana Długosza z lat 70-tych XV w. oraz Liber retaxationum z 1529 r., przy czym to ostatnie źródło choć wspomina kanonię pierzchnicką, jednak całkowice pomija jej opis - patrz J. Długosz, Liber beneficiorum dioecesis Cracoviensis, t. I (dalej DLB), w: Opera omnia Joannis Dlugosii, wyd. J. Łętowski, t. VII, Kraków 1863, s. 437-476 oraz Księa dochodów beneficjów diecezji krakowskiejzroku 1529 (tzw.Liber retaxationum), wyd.Z. Leszczyńska-Skrętowa, Wrocław 1968, s. 3757, 381-382, 400. O tym, że kapituła kielecka przed wspomnianym wyżej rokiem 1350 liczyła 9 członków przekonują spisy dziesięciny papieskiej. Dwa pierwsze przekazują informacje o 4 prałatach i 5 kanonikach. Szósty kanonik pojawił się dopiero w wykazie za 1350/1351 r. (ACA t. I, s. 166-168, 241-243; t. II, s. 369-370).

${ }^{2}$ J. Szymański, Kanonicy świeccy narzędziem feudalnej organizacji włości kieleckiej biskupów krakowskich na przełomie XII i XIII w., „Rocznik Muzeum Świętokrzyskiego”, 3 (1966) s. $305-$ 327.

${ }^{3} \mathrm{~S}$. Trawkowski, Zagadka prepozytury tarskiej, w: Mente et litteris. O kulturze i społeczeństwie wieków średnich, Poznań 1984, s. 175-187 oraz w: Opuscula mediaevistica. Studia nad historia spoteczna Polski wczesnopiastowskiej, Warszawa 2005, s. 132-146. 
Najpełniej problematyka ta została poruszona niemal pół wieku temu przez J. Szymańskiego, który doszedł do wniosku, że pełny skład kapituły kieleckiej jest poświadczony już w roku 1229. Miała się ona składać w tym czasie z 7 prałatów i kanoników. Teza taka oparta jest na analizie treści dokumentu biskupa Iwona Odrowąża z 18 I 1229 r. Został on wystawiony w Kielcach a w jego testacji wymieniono 3 prałatów (dziekana, scholastyka i kustosza) oraz 3 kanoników ${ }^{4}$. Ponieważ istnienie prepozytury jest potwierdzone już w roku $1214^{5}$, zatem w roku 1229 kapituła kielecka składała się dowodnie z co najmniej 4 prałatur i 3 kanonii. Co prawda trudno jednoznacznie stwierdzić, czy pozostałe kanonie w tym czasie jeszczenie istniały, czy teżzostały pominięte, wydaje sięjednak, że dokumentz 1229 r. oddaje pełny skład ówczesnej kapituły, wymagający uzupełnienia o osobę prepozyta. Wnosić o tym można na podstawie liczby wikariuszy kieleckich wymienionych w dalszej części testacji cytowanego dokumentu. Było ich siedmiu, tj. tylu ilu prałatów i kanoników. Wydaje się mało prawdopodobne, aby liczba znanych dla tego czasu prałatów i kanoników zupełnie przypadkowo odpowiadała liczbie wikariuszy. Bardziej prawdopodobne jest przypuszczenie J. Szymańskiego, że w 1229 r. kapituła kielecka składała się rzeczywiście z 7 prałatów i kanoników $^{6}$, których wspierali odpowiadający im liczebnie wikariusze ${ }^{7}$. Co więcej zdaniem J. Szymańskiego prałatury i kanonie kieleckie posiadały w tym czasie odrębne prebendy, wydzielone tak pod względem prawnym, jak i majątkowym ${ }^{8}$. Dowodem na poparcie takiego twierdzenia jest poświadczone źródłowo istnienie od 1213 r. prebendy kanonickiej w Kielcach posiadającej wydzielone uposażenie$^{9}$. Dalej J. Szymański analizując uposażenie członków kapituły kieleckiej do-

${ }^{4}$ Diplomata monasterii Clarae Tumbae prope Cracoviam (dalej KMog), wyd. E. Janota, Kraków 1865 , nr 9, s. 7-8.

${ }^{5}$ Kodeks dyplomatyczny Małopolski (dalej KDM), t. II, wyd. F. Piekosiński, Kraków 1876, nr 383, s. 26.

${ }^{6}$ Szymański, Kanonicy świeccy, s. 313.

${ }^{7} \mathrm{Na}$ marginesie wyjaśnienia wymaga obecność w składzie kapituły kieleckiej osoby magistra Ganfridusa, który w kapitule musiał zajmować wysoką pozycję, skoro wymieniony został po prałatach a przed kanonikami i wikariuszami. Jak słusznie dowiódł J. Szymański był to przełożony szkoły kolegiackiej w Kielcach (J. Szymański, Szkolnictwo kanonickie w Małopolsce XIII wieku, „Rozprawy z Dziejów Oświaty i Wychowania”, 8 (1965), s. 3-15; Tenże, O źródłach pisanych do dziejów Kielc w średniowieczu, „Rocznik Muzeum Świętokrzyskiego”, 8 (1973), s. 45). Do wniosku takiego uprawnia analiza XV-wiecznego opisu scholasterii kieleckiej zawartego w Liber beneficiorum Jana Długosza. Po scharakteryzowaniu źródeł dochodu scholastyka i wicescholastyka kieleckiego Jan Długosz wspomniał, że scholasterii kieleckiej podlegała szkoła, której przełożony [magister scholae] był utrzymywany przez scholastyka (DLB t. I, s. 451-452).

${ }^{8}$ Szymański, Kanonicy świeccy, s. 313.

${ }^{9}$ Była to kanonia zwana później żydowską. Powstała on poprzez przeniesienie prebendy plebańskiej z Kijów do Kielc. Źródło nie określa dokładnie uposażenia prebendy, jednak informuje, że uposażenie takie było wydzielone a co więcej w $1213 \mathrm{r}$. powiększyło się o dochody z wsi Podłęże - patrz Kodeks dyplomatyczny katedry krakowskiej św. Wactawa (dalej KDKK), cz. I, wyd. F. Piekosiński, Kraków 1874, nr 9, s. 13-14. Szerzej przeniesienie prebendy z Kijów do Kielc omawiają: W. Pałucki, Kasztelania czechowska, Warszawa 1964, s. 24-25; E. Wiśniowski, Rozwój sieci parafialnej w prepozyturze wiślickiej w średniowieczu, Warszawa 1965, s. 69; J. Szymański, Możno- 
chodzi do wniosku, że do grona najwcześniej utworzonych należy zaliczyć wszystkie znane później prałatury oraz kanonie: pierzchnicką, brzechowską i sieradowicką. Zdaniem J. Szymańskiego wskazuje na to ich wspólne źródło uposażenia. Jak zauważa „stanowią je dochody najstarszych kościołów w rejonie Gór Świętokrzyskich, a mianowicie w Kielcach (kościół św. Wojciecha, będący pierwotnie kościołem książęcym), Świętomarzy oraz w Starym Radomiu ${ }^{10}$ ". W tym miejscu rodzi się wątpliwość co autor rozumie pod użytym przez niego sformułowaniem: „najstarszy skład prebend w kościele kieleckim”. Z kontekstu wynikałoby, że chodzi o prebendy utworzone przed 1229 r., jednak w takiej sytuacji mamy do czynienia z pewną niekonsekwencją. Autor opowiedział się bowiem wcześniej za tym, że dokument z 1229 r. poświadcza istnienie jedynie 7 prebend prałackich i kanonickich. W tej sytuacji uznane przez niego za najstarsze prałatury i kanonie w połączeniu z kanonią żydowską powstałą w 1213 r. dawałyby w 1229 r. liczbę 8 a nie 7 prebend. Wyjaśnienia tej sprzeczności można dopatrywać się bądź w hipotetyczności istnienia tylko 7 prebend w roku 1229, bądź w przypuszczeniu J. Szymańskiego, że prepozyt kielecki mógł być w tym czasie oddelegowany do innych zadań związanych z zarządem dóbr biskupich w rejonie Tarczku ${ }^{11}$. Niepewność jednak pozostaje, bo autor nie opowiedział się jednoznacznie, że oznaczało to wyłączenie go z kapituły kieleckiej.

Zdaniem J. Szymańskiego w dalszej kolejności miały powstać kanonie szydłówecka i szewieńska. O pierwszej da się powiedzieć jedynie, że jej uposażenie w największej części stanowiły dziesięciny z okolic Chęcin, czyli dóbr książęcych leżących na terenie arcybiskupstwa gnieźnieńskiego. Oznacza to zdaniem autora, że w jej utworzenie zaangażowani byli: biskup krakowski, książę i arcybiskup

władztwo małopolskie a kanonikat świecki w I połowie XII wieku, „Małopolskie Studia Historyczne”, 10 (1967) z. 1-2, s. 41; Tenże, Kanonikat świecki w Małopolsce od końca XI do połowy XIII wieku, Lublin 1995, s. 33, 96; J. Wroniszewski, O początkach kościoła w Kijach, w: Cursus mille annorum. Prace ofiarowane Profesorowi Eugeniuszowi Wiśniowskiemu, „Roczniki Humanistyczne”, 48 (2000) z. 2 - zeszyt specjalny, s. 626-627. Przy czym poszczególni autorzy różnią się w sposobie rekonstrukcji stanu panującego w Kijach przed wystawieniem dokumentu Wincentego Kadłubka. Zdaniem J. Szymańskiego w Kijach przed 1213 r. istniała grupa kanonicka. Ma o tym świadczyć istnienie w $1213 \mathrm{r}$. trzech prebend przy kościele kijskim, z których jedna została przeniesiona do Kielc mocą decyzji biskupa Wincentego (Szymański, Możnowładztwo małopolskie, s. 41; Tenże, Kanonikat świecki, s. 33, 96; Tenże, Geneza organizacji parafialnej w Polsce, „Przegląd Historyczny”, 55 (1964) z. 3, s. 506). E. Wiśniowski wspomina o dwóch prebendach plebańskich, przy czym uważa, że w 1213 r. Wincenty Kadłubek obie wcielił do kapituły kieleckiej (Wiśniowski, Rozwój sieci parafialnej, s. 68-69). Natomiast zdaniem W. Pałuckiego a za nim J. Wroniszewskiego przy kościele w Kijach przed 1213 r. istniały dwie prebendy plebańskie, z których jedna została przeniesiona do Kielc w 1213 r., natomiast druga pozostała w rękach rodu Powałów (Pałucki, Kasztelania czechowska, s. 24-25, Wroniszewski, O poczatkach, s. 626-627). Argumentacja przytoczona przez J. Wroniszewskiego jak i uważna lektura dokumentu ostatecznie wskazuje na słuszność tego ostatniego poglądu.

${ }^{10}$ Szymański, Kanonicy świeccy, s. 314.

${ }^{11}$ Wiązało się to z pojawieniem się w źródłach prepozyta w Tarczku, którym w 1228 r. był Prandota. Zdaniem J. Szymańskiego w 1239 r. ten sam Prandota był prepozytem kieleckim - Szymański, Kanonicy świeccy, s. 312. 
gnieźnieński. Trudno jednak ustalić czas powstania kanonii szydłóweckiej poza ogólnikowym stwierdzeniem, że nastąpiło to po 1229 r. $^{12}$

Co do kanonii szewieńskiej, to fakt uposażenia jej dziesięcinami z terenu parafii w Szewnej oznacza, że powstała ona już po erygowaniu parafii a to zdaniem J. Szymańskiego nastąpiło zapewne w pierwszej połowie XIII w. ${ }^{13} \mathrm{~W}$ tej sytuacji powstanie kanonii szewieńskiej wspomniany autor odnosi do połowy XIII w. ${ }^{14}$

Przedstawione przez J. Szymańskiego ujęcie problemu, bazujące na analizie dostępnych źródeł ukazuje etapy kształtowania się kapituły kieleckiej. Wydaje się jednak, że w oparciu o istniejącą bazę źródłową można dojść do nieco innych wniosków. W rozważaniach na ten temat jako punkt wyjścia należy potraktować dokument biskupa Iwona Odrowąża. Przede wszystkim należy skonstatować, że w połączeniu z wcześniejszymi wzmiankami poświadcza on istnienie na początku drugiej ćwierci XIII w. wszystkich prałatur kieleckich znanych z późnego średniowiecza. Co więcej można ze sporym prawdopodobieństwem twierdzić, że wszystkie prałatury istniały już wcześniej. Istnienie kustodii poświadczone jest już w roku $1212^{15}$. Dwa lata później w dokumentach pojawili się dziekan i prepozyt kielecki ${ }^{16}$. Jedynie scholastyk po raz pierwszy pojawił się w $1229 \mathrm{r}$. W tym miejscu koniecznie trzeba rozważyć, czy we wszystkich przytoczonych wyżej wzmiankach mowa była o prałatach posiadających wydzielone prebendy. Pierwsza połowa XIII w. to czas kiedy w kapitułach dochodzi do niezwykle istotnych przemian. Wspólnotowy charakter kapituł nie przystaje do nowych uwarunkowań i zadań jakie stawiane są tym instytucjom. Jest to okres uzyskiwania przez kapituły większej samodzielności ${ }^{17}$, przy jednoczesnym odejściu od zasady vita communis. Przejawia się to m.in. w porzuceniu obowiązującej dotychczas zasady wspólnoty majątkowej. Jako pierwsze wyodrębniły się najpewniej prebendy osób kierujących kapitułami - a więc najczęściej prepozytów. W dalszej kolejności wyodrębnieniu z majątku wspólnego podlegały pozostałe prebendy prałackie i kanonickie $^{18}$.

W przypadku Kielc pierwsza prebenda, której czas powstania można uznać za pewny, została utworzona w roku 1213. Była to kanonia zwana później żydowską. Jeżeli zatem w 1213 r. mogła powstać odrębna prebenda kanonicka, to wydaje się,

${ }^{12}$ Szymański, Kanonicy świeccy, s. 314.

${ }^{13}$ Podobnie czas powstania parafii w Szewnej datuje H. Grocholski - patrz tegoż Sieć parafialna archidiakonatu zawichojskiego do końca XVI wieku, Lublin 1956, s. 37 (rkps w Archiwum Uniwersyteckim KUL, sygnatura H.m. 334).

${ }^{14}$ Szymański, Kanonicy świeccy, s. 315.

${ }^{15} 24$ V 1212 r. w testacji dokumentu biskupa Wincentego Kadłubka pojawił się kustosz kielecki o imieniu Vichardus - KDM I nr 9, s. 15.

${ }^{16}$ Dziekan Jan i prepozyt Wojciech - KDM t. II, nr 383, s. 26.

${ }^{17}$ Przejawem nabywania w tym czasie samodzielności przez kapituły kolegiackie jest przywieszenie do cytowanego wyżej dokumentu biskupiego z 1229 r. pieczęci kapituły kieleckiej i wiślickiej. Znamienny ten fakt poświadcza uzyskanie osobowości prawnej przez obie kapituły kolegiackie (patrz L. Poniewozik, Prałaci i kanonicy wiśliccy w okresie średniowiecza, Lublin 2004 (ed. 2005), s. 14).

${ }^{18}$ J. Szymański, Kanonikat świecki w Małopolsce od końca XI do połowy XIII wieku, Lublin 1995, s. 118. 
że nie później wyodrębniły się także prebendy prałackie i pozostałe kanonickie. Wydaje się więc bardzo prawdopodobne, że dokument z 1229 r. poświadcza istnienie co najmniej 7 prawnie wydzielonych prebend: 4 prałackich i 3 kanonickich $^{19}$. Fakt że scholasteria kielecka została po raz pierwszy odnotowana w 1229 r. nie musi oznaczać jej późniejszego w stosunku do innych prałatur wyodrębnienia ${ }^{20}$. Według tradycji przekazanej przez Jana Długosza dochody parafii św. Wojciecha w Kielcach stały się podstawą ufundowania kapituły kieleckiej. Jeśli tak to scholasteria, która była uposażona dochodami świątyni p.w. św. Wojciecha, mogła powstać już wcześniej. Przecież kustodia, która także posiadała w ramach uposażenia dochody przejęte z kościoła św. Wojciecha, pojawiła się w źródłach jako pierwsza, nawet przed prepozytura i dziekanią. Wreszcie - jak słusznie zauważył J. Szymański - w 1213 r. aby utworzyć kanonię żydówecką trzeba było szukać dla niej uposażenia „poza Kielcami, a nawet poza dobrami kieleckimi biskupów krakowskich" 21 to znaczy, że dobra te były już rozparcelowane. Ponieważ scholasteria była uposażona na dochodach pierwotnej parafii kieleckiej ${ }^{22}$, to jej utworzenie przed rokiem 1229, a nawet 1213, wydaje się niemal pewne, natomiast jej niskie uposażenie musiało mieć inne przyczyny niż późne powstanie ${ }^{23}$.

Podsumowując dotychczasowe rozważania należy stwierdzić, że w $1229 \mathrm{r}$. mamy poświadczone istnienie 7 prebend w kapitule kieleckiej. Możliwe również, że - zgodnie z przypuszczeniem J. Szymańskiego - taki kształt kapituła otrzymała na drodze reorganizacji dokonanej przez biskupa Wincentego Kadłubka a data tej reorganizacji uświetniona została konsekracją kolegiaty kieleckiej, być może w roku $1213^{24}$ ? Jeśli nawet zaproponowana przez J. Szymańskiego data, czy osoba inicjatora reorganizacji kapituły kieleckiej nie jest poprawna, to błąd z pewnością nie jest wielki. Ostrożniej można stwierdzić, że stało się to za czasów bądź Wincentego Kadłubka, bądź Iwona Odrowąża, przy czym przytoczona argumentacja przemawia raczej za tym pierwszym ${ }^{25}$.

${ }^{19} \mathrm{Ku}$ takiej tezie skłania się także J. Szymański - patrz tegoż Kanonicy świeccy, s. 312.

${ }^{20}$ Pogląd taki przedstawił J. Szymański - patrz tegoż, Kanonicy świeccy, s. 314.

${ }^{21}$ Szymański, Kanonicy świeccy, s. 315.

${ }^{22} \mathrm{~W}$ XV w. uposażenie scholasterii przejęte z parafii św. Wojciecha ograniczało się do wsi Zagórze koło Kielc (DLB t. I, s. 449-450). Należy jednak pamiętać - o czym będzie mowa niżej - że dochody scholasterii pierwotnie obejmowały dziesięcinę zbożową z Kielc (KDKK cz. I, nr 234, s. 300301; DLB t. I, s. 450).

${ }^{23}$ J. Szymański domyśla się, że niskie dochody scholasterii (w XIV w. było to 5 grz.) wynikały z tego, że została ona utworzona „ze zwykłej kanonii” ( Szymański, Kanonicy świeccy, s. 314). Warto jednak pamiętać, że w XIV w. „zwykłe kanonie” w Kielcach otaksowano na 18, 10, 10, 7, 5 i $21 / 2$ grz. Rodzi się zatem pytanie, dlaczego - zgodnie z koncepcją J. Szymańskiego - tworząc scholasterię zrobiono to na bazie ubogiej a nie bogatej kanonii?

${ }^{24}$ Szymański, Kanonicy świeccy, s. 315.

${ }^{25}$ Tamże, s. 315. Warto tu przypomnieć dostrzeżoną przez J. Szymańskiego notatkę z kroniki Jana Długosza poświadczającą istnienie jeszcze w XV w. tradycji wiążącej Wincentego Kadłubka z utworzeniem kapituły kieleckiej (Szymański, O źródłach pisanych, s. 59, sama notatka patrz - Ioannis Dlugossii Annales seu cronicae incliti Regni Poloniae, liber 5-6, Warszawa 1973, s. 238). Tradycja ta musiała być sprzeczna dla ludzi późnego średniowiecza z przekazem o dokonaniu fundacji przez biskupa Gedkę. 
W tej sytuacji pozostaje do rozważenia w jakiej kolejności pojawiały się poszczególne kanonie. Przyjmując za J. Szymańskim, że w 1229 r. było ich jedynie 3, można ponad wszelką wątpliwość stwierdzić, że jedną $\mathrm{z}$ nich była kanonia zwana później żydowską ${ }^{26}$. Starając się ustalić, które spośród znanych w XV w. kanonii (oprócz żydowskiej) istniały przed 1229 r., znowu trzeba się oprzeć na przekazie Długosza o okolicznościach ufundowania kapituły na bazie dochodów kościoła św. Wojciecha. Wydaje się rzeczą najbardziej prawdopodobną, że w gronie kanonii posiadających w swym uposażeniu elementy dochodów najwcześniejszej parafii kieleckiej należy upatrywać pozostałych dwóch kanonii z $1229 \mathrm{r}$. Wśród XV-wiecznych prebend kanonickich aż trzy posiadały w swym uposażeniu takie ślady. Były to kanonie pierzchnicka, brzechowska i szydłówecka ${ }^{27}$. Przyglą-

${ }^{26} \mathrm{~W}$ tym miejscu doprecyzowania wymaga jeszcze sprawa wartości dochodu jaki uzyskiwała kanonia żydowska. J. Szymański uznaje, że w XIV w. kanonia ta została otaksowana na 18 grz. Wniosek taki opiera na analogii - kanonia żydowska w świetle Długoszowej Liber beneficiorum stała na pierwszym miejscu w hierarchii kanonii i uzyskiwała najwyższy dochód a zatem w XIV w. zdaniem J. Szymańskiego musiała zajmować tę samą pozycję i była najbogatsza. Takie założenie może, ale nie musi być słuszne. Hierarchia prebend znana z XV w. nie zawsze odpowiadała hierarchii z XIV stulecia. Dość przypomnieć zmiany jakie w tym względzie zachodziły wśród prałatów kieleckich (porównaj Acta Camerae Apostolicae (dalej ACA), t. I, wyd. J. Ptaśnik, w: Monumenta Poloniae Vaticana, t. I, Kraków 1913, s. 167, 242; t. II, Kraków 1914, s. 369-370, 403, 419 i DLB t. I, s. 449, 452) sandomierskich (L. Poniewozik, Prałaci i kanonicy sandomierscy w okresie średniowiecza, Toruń 2004 (ed. 2005), s. 27) czy wiślickich (Poniewozik, Prałaci i kanonicy wiśliccy, s. 20). Natomiast wartość uzyskiwanych dochodów była sprawą niezwykle zmienną. Dla przykładu kanonia żydowska w czasach Jana Długosza uzyskiwała rzeczywiście najwyższy dochód wśród kanoników kieleckich, ale już w 1529 r., czyli ok. 60 lat później, zajmowała zaledwie czwarte miejsce pod względem zamożności, przy czym kanonii pierzchnickiej ustępowała o ponad 10 grz. a szewieńskiej o 25,5 grz., czyli niemal dwukrotnie (L. Poniewozik, Uposażenie prałatur i kanonii średniowiecznych kapitut kolegiackich $w$ diecezji krakowskiej, [w druku], tabela nr. 3). Co więcej w rejestrze poborowym z 1539 r., który podaje jeszcze XIV-wieczne taksy beneficjów diecezji krakowskiej, na czele kanonii kieleckich postawiono kanonię szydłówecką i to jej przypisano taksę 18 grz., podczas gdy kanonia żydowska znalazła się na miejscu trzecim z najniższą taksą (2,5 grz.!!!) - patrz Regestrum contributionis duplae iuxta taxam antiquam episcopatus et omnium beneficiorum dioecesis Cracoviensis ad annum 1539 in synodo Piotrcoviensis provinciali decretum (ABMK 1047), $\mathrm{k}$. 64 i 65. Przy takiej rozbieżności informacji źródłowych na temat pozycji kanonii żydowskiej w kapitule i jej dochodów trudno stwierdzać czy rzeczywiście była w XIV w. najbogatszą kanonią a co za tym idzie czy zajmowała wówczas pierwsze miejsce.

${ }^{27} \mathrm{~W}$ przypadku kanonii pierzchnickiej fakt ufundowania jej dochodów na wcześniejszym uposażeniu parafii św. Wojciecha znajduje odzwierciedlenie w stosunkach panujących w XV w. Według Liber beneficiorum kanonia ta w ramach fundum posiadała dochody z łanów miejskich w Kielcach. Pierwotnie jej uposażenie w jeszcze większym stopniu wiązało się z Kielcami, bowiem do $1359 \mathrm{r}$. czerpała ona dochody z karczem kieleckich, jednak 2 II 1359 r. kanonik Tomisław zamienił wpływy z karczem na dziesięcinę z wsi Pierzchnica (KDKK t. I, nr 215, s. 272).

Co do kanonii szydłóweckiej to Jan Długosz zanotował, że została uposażona na dochodach parafii św. Wojciecha. W XV w. da się odnaleźć materialny ślad tego faktu. Wg Liber beneficiorum wieś Szydłówek należąca do parafii kolegiackiej w Kielcach, oddawała czynsz i dziesięcinę na rzecz wikariusza kanonii szydłóweckiej (DLB t, I, s. 465 i 468 - co prawda oba opisy różnią się i raz przyznają dochody z Szydłówka kanonii innym razem wikarii, jednak zważywszy na to, że wika- 
dając się uważniej uposażeniu wszystkich prebend w kapitule kieleckiej z łatwością można zauważyć, że kanonia pierzchnicka i brzechowska oraz kustodia i scholasteria były ze sobą ściśle powiązane. Kustodia i kanonia pierzchnicka oraz scholasteria i kanonia brzechowska stanowią swego rodzaju „pary uposażeniowe”. I tak w przypadku kustosza i kanonika prebendy pierzchnickiej obaj mieli fundum oparte na tych samych dochodach (dziesięciny snopowe z łanów miejskich w Kielcach i po 1 łanie w Mąchocicach ${ }^{28}$ ) a ponadto pobierali dziesięciny z tych samych miejscowości (patrz tabela nr 1).

riusz nie miał prawie nic oprócz wpływów z Szydłówka, należy uznać, że to był rzeczywiście jego - a nie kanonika - dochód). Możliwe także, że pierwotnie uposażenie kanonii szydłóweckiej oparte na dawnych dochodach kościoła św. Wojciecha było większe. W XIV w. biskupi krakowscy starali się przejąć z rąk prałatów i kanoników kieleckich atrakcyjne - z ich punktu widzenia - elementy uposażenia oddając w zamian inne. Przykładem może być cytowana wyżej zamiana dokonana pomiędzy Bodzantą a kanonikiem Tomisławem. $10 \mathrm{~V} 1359$ r. Bodzanta zamienił z innym kanonikiem kieleckim dziesięciny z Obic, Ostrowa i Łukowa na dziesięciny zbożowe z Kielc i dochody z karczem w Tarczku (KDKK t. I, nr 216, s. 273). Uzyskane w ten sposób dziesięciny w XV w. stanowiły uposażenie kanonii brzechowskiej (DLB t. I, s. 474, 475). Wreszcie 1 X 1364 r. biskup Bodzanta zamienił ze scholastykiem kieleckim dziesięcinę z Umianowic na dochody z karczem w Tarczku i dziesięcinę zbożową z Kielc (KDKK t. I, nr 234, s. 300-301; DLB t. I, s. 450). Jest zatem możliwe, że także kanonia szydłówecka pierwotnie posiadała uposażenie oparte na dochodach z Kielc, które następnie zostało zamienione na inne dochody. Warto zwrócić uwagę, że dochody kanonii szydłóweckiej wiązały ją z rejonem Chęcin - stamtąd pochodziła większość (sześć na dziewięć) czerpanych przez tę kanonię dziesięcin (DLB t. I, s. 466-468). Jedynie trzy dziesięciny kanonia ta otrzymywała z wsi leżących w parafii Młodzawy, a zatem w znacznej odległości od Chęcin (DLB t. I, s. 465-466). Może to jest ślad jakiejś zamiany z biskupem krakowskim?

${ }^{28}$ Co prawda przy opisie wicekanonii pierzchnickiej mowa jest o tym, że właścicielem 1 łanu w Mąchocicach był wikariusz (Item [vicarius] habet in villa Mochoczicze unum laneum cmethonalem...) i on też pobierał z niego czynsz i dziesięcinę (DLB t. I, s. 373-374), jednak opis kanonii ujmuje cała rzecz inaczej. Mowa jest tam o tym, że należny kanonikowi czynsz i dziesięcinę pobierał wikariusz (DLB t. I, s. 373). Taki stan rzeczy wynikał zapewne z nadania jakiego dokonał kanonik przekazując swemu wikariuszowi zarówno prawo własności jak i opłaty z Mąchocic. Śladem dawnych stosunków było zachowanie przez kanonika prawa do danin w naturze, tj. do 3 miar owsa płaconych przez kmiecia z omawianego łanu. Fakt ten podkreślono w obu opisach - zarówno odnoszącym się do uposażenia kanonii, jak i wicekanonii (DLB t. I, s. 373 i 374). Można zatem przyjąć, że pierwotnie łan w Mąchocicach stanowił dodatkowe fundum kanonii pierzchnickiej. 
Tabela nr 1: Elementy składowe uposażenia kustodii i kanonii pierzchnickiej w czasach Jana Długosza ${ }^{29}$.

\begin{tabular}{|c|c|c|c|c|}
\hline \multirow[t]{2}{*}{ L.p. } & \multirow[t]{2}{*}{ Nazwa wsi } & \multirow[t]{2}{*}{ Parafia } & \multicolumn{2}{|c|}{$\begin{array}{c}\text { Odnotowana przez Jana } \\
\text { Długosza } \\
\text { w ramach uposażenia }\end{array}$} \\
\hline & & & kustodii & $\begin{array}{c}\text { kanonii } \\
\text { pierzchnickiej }\end{array}$ \\
\hline 1. & Kielce & Kielce & + & + \\
\hline 2. & $\begin{array}{c}\text { Mąchocice } \\
\text { [Mąchocice Kapitulne] }\end{array}$ & Kielce & + & $(+)^{*}$ \\
\hline 3. & Krajno & Daleszyce & + & + \\
\hline 4. & $\begin{array}{c}\text { Cisów } \\
\text { [Cisów Rządowy] }\end{array}$ & Daleszyce & + & + \\
\hline 5. & Sędziejowice & Sędziejowice & + & + \\
\hline 6. & Śladków & Sędziejowice & + & + \\
\hline 7. & Bardo & Bardo & + & + \\
\hline 8. & Czyżów & Bardo & + & + \\
\hline 9. & Nida & Brzeziny & + & - \\
\hline 10. & Włoszczowice & Piotrkowice & + & - \\
\hline 11. & Kliszów & Kije & + & + \\
\hline 12. & Pierzchnica & Pierzchnica & - & + \\
\hline
\end{tabular}

* Z powodów opisanych w przypisie nr 26, Mąchocice warunkowo umieszczam pośród uposażenia kanonii pierzchnickiej.

Uposażenie kustodii i kanonii pierzchnickiej nawet w czasach Jana Długosza było dostatecznie podobne, aby nie ulegało wątpliwości wzajemne ich powiązanie. Wydaje się jednak, że do połowy XIV w. związki prałatury i kanonii były jeszcze bardziej ścisłe. Jan Długosz opisując wieś stanowiącą fundum kanonii pierzchnickiej zanotował, że stała się ona jej własnością dopiero w roku 1359. Wcześniej zamiast dziesięciny z Pierzchnicy kanonik pobierał dochody z karczem w Kielcach. Zamiana uposażenia dokonała się z inicjatywy biskupa krakowskiego Bodzenty $^{30}$. W tej sytuacji uposażenie kustodii i kanonii przed 1359 r. było jeszcze bardziej podobne niż w czasach Długosza. Łatwo też zauważyć, że przed 1359 r. elementami różniącymi prałaturę i kanonię były jedynie dochody z Nidy i Włoszczowic (patrz tab. nr 1), przy czym Nidę znajdziemy w uposażeniu wicekanonii

${ }^{29}$ Dane do tabeli na podstawie DLB t. I, s. 452-456, 472-473 (kustodia) i DLB t. I, s. 452-455, 457, 470-474 (prebenda pierzchnicka). Dokonanie porównania skąd kustodia i kanonia pierzchnicka czerpały dochody w roku 1529 jest poważnie utrudnione z powodu pominięcia przez Liber retaxationum opisu prebendy pierzchnickiej. Zachowany wykaz uposażenia kustodii i znajdujące się w nim gdzieniegdzie wzmianki o „dzieleniu się” dochodem z kanonikiem prebendy pierzchnickiej przekonuje, że sytuacja od czasów Jana Długosza nie uległa istotnym zmianom - patrz LR 1529 375-376.

${ }^{30}$ DLB t. I, s. 470. 
pierzchnickiej ${ }^{31}$. Tak więc wyłącznie dziesięcina z Włoszczowic różniła w sposób istotny kustodię i kanonię pierzchnicką. Fakt ten może rodzić przypuszczenie, że kustodia nie posiadała początkowo dziesięciny z Włoszczowic a uzyskała ją w wyniku nieudokumentowanej źródłowo zamiany. Co więcej w świetle podobieństwa uposażenia obu prebend musiałaby być to zamiana analogiczna do tej, jaka stała się udziałem kanonii pierzchnickiej. Oczywiście stawianie takiej tezy byłoby nieuprawnione, gdyby nie podobne okoliczności w jakich scholasteria i kanonia brzechowska zamieniły z biskupem krakowskim wspólne dochody z Kielc i Tarczku na dziesięciny z różnych miejscowości (patrz niżej). W świetle powyższych rozważań można zaryzykować twierdzenie, że uposażenie kustodii i kanonii pierzchnickiej $\mathrm{w}$ okresie poprzedzającym połowę XIV w. było praktycznie identyczne (patrz tabela nr 2).

Tabela nr 2: Przypuszczalne uposażenie kustodii i kanonii pierzchnickiej w czasach sprzed połowy XIV w.

\begin{tabular}{|c|c|c|c|c|}
\hline L.p. & Nazwa wsi & Parafia & $\begin{array}{c}\text { Uposażenie kusto- } \\
\text { dii }\end{array}$ & $\begin{array}{c}\text { Uposażenie kanonii } \\
\text { pierzchnickiej }\end{array}$ \\
\hline 1. & Kielce & Kielce & + & + \\
\hline 2. & $\begin{array}{c}\text { Mąchocice } \\
\text { [Mąchocice Kapitulne] }\end{array}$ & Kielce & + & + \\
\hline 3. & Krajno & Daleszyce & + & + \\
\hline 4. & Cisów & Daleszyce & + & + \\
\hline 5. & Sędziejowice & Sędziejowice & + & + \\
\hline 6. & Śladków & Sędziejowice & + & + \\
\hline 7. & Bardo & Bardo & + & + \\
\hline 8. & Czzýów & Bardo & + & + \\
\hline 9. & Nida & Brzeziny & + & + \\
\hline 10. & Kliszów & Kije & + & + \\
\hline
\end{tabular}

* Należy pamiętać, że w czasach Długosza dochody z Nidy stanowiły uposażenie wikariusza kanonii pierzchnickiej.

W przypadku scholastyka jak i kanonika prebendy brzechowskiej w świetle danych zawartych w Liber beneficiorum i Liber retaxationum analogia w zakresie uposażenia nie jest widoczna. Obie prebendy czerpały dochody z zupełnie różnych źródeł (patrz tabele $\mathrm{nr} 3$ ).

${ }^{31}$ DLB t. I, s. 473. W innym miejscu Jan Długosz zanotował, że dziesięcinę z Nidy pobierał nie wikariusz a kanonik, ponieważ jednak dzieje się tak przy opisie kustodii kieleckiej (DLB t. I, s. 453) a wśród informacji na temat uposażenia kanonii pierzchnickiej Nida nie została uwzględniona, należy dać wiarę opisowi ze s. 473. Mimo to wydaje się, że sytuacja z dziesięciną z Nidy przypomina dzieje dochodu z Mąchocic - pierwotnie należący do kanonii znalazł się w uposażeniu wikarii. 
Tabela nr 3: Elementy skladowe uposażenia scholasterii i kanonii brzechowskiej w Kielcach w czasach Jana Długosza i roku $1529^{32}$.

\begin{tabular}{|c|c|c|c|c|}
\hline \multirow{2}{*}{ L.p. } & \multirow{2}{*}{ Nazwa wsi } & \multirow{2}{*}{ Parafia } & \multicolumn{2}{|c|}{ Odnotowana w } \\
\hline & & & DLB & $1529 \mathrm{r}$. \\
\hline \multicolumn{5}{|c|}{ Scholasteria } \\
\hline 1. & Zagórze & Kielce & + & + \\
\hline 2. & Złota & św. Piotra w Sandomierzu & + & + \\
\hline 3. & Umianowice & Kije & + & + \\
\hline 4. & Wierzbie & Drugnia & + & + \\
\hline \multicolumn{5}{|c|}{ Kanonia brzechowska } \\
\hline 1. & Brzechów & Daleszyce & + & + \\
\hline 2. & Obice & Lisów & + & + \\
\hline 3. & Jawor & Chomentów & + & + \\
\hline 4. & Karsy & Kije & + & + \\
\hline 5. & Lipa & Kije & + & + \\
\hline 6. & Łukowa & Łukowa & + & + \\
\hline
\end{tabular}

Należy jednak pamiętać, że scholasteria do 1364 r. zamiast dziesięcin z Umianowic posiadała uposażenie oparte na dziesięcinach z Kielc oraz dochodach z karczem w Tarczku ${ }^{33}$. Podobnie było w przypadku prebendy brzechowskiej, która także do pewnego momentu posiadała dziesięciny z łanów miejskich w Kielcach oraz wpływy z karczem tarskich. Sytuacja taka miała miejsce do $10 \mathrm{~V} 1359 \mathrm{r}$. W tym dniu kanonik Jan zamienił z biskupem Bodzentą dochody z Kielc i Tarczku na dziesięcinę z Obic, Łukowa i Ostrowa ${ }^{34}$. Ostatecznie kanonia uzyskała dziesięciny z Obic i Łukowa ${ }^{35}$ natomiast dochody z Ostrowa z nieznanych powodów zachował biskup ${ }^{36}$. W tym miejscu rodzi się pytanie, czy brak dziesięcin z Ostrowa nie został kanonii zrekompensowany przez biskupa w jakiś inny sposób? Do zagadnienia tego jeszcze powrócę. Analizując uposażenie kanonii brzechowskiej znane z XV i XVI w. uwagę zwraca niewielki kompleks dochodów pochodzących ze zwartego terytorium. Były to dziesięciny z wsi Jawor, Karsy i Lipa. Co więcej miejscowości te do 1331 r. należały do parafii w Kijach ${ }^{37}$. Taki stan rzeczy móg-

${ }^{32}$ Dane do tabeli na podstawie:

Scholasteria - DLB t. I, s. 449-451; LR 1529 s. 382.

Kanonia brzechowska - DLB t. I, s. 474-475; LR 1529 s. 400.

${ }^{33}$ KDKK t. I, nr 234, s. 300-301; DLB t. I, s. 450.

${ }^{34}$ KDKK t. I, nr 216, s. 273 - w dokumencie nie wspomniano, którą kanonię kielecką posiadał Jan, jednak uzyskane przez niego dziesięciny jednoznacznie wskazują na kanonię brzechowską porównaj DLB t. I, s. 474-475.

${ }^{35}$ DLB t. I, s. 474-475.

${ }^{36}$ Dziesięcinę z Ostrowa w parafii Brzeziny (okolice Chęcin) biskup pobierał dowodnie w roku 1529 r. (LR 1529, s. 24). Jan Długosz nie wymienił Ostrowa w zachowanych częściach Liber beneficiorum, bowiem wieś ta leżała poza terenem diecezji krakowskiej. Zapewne została wymieniona w zaginionej części poświęconej uposażeniu biskupstwa krakowskiego.

${ }^{37}$ Przynależność wsi Karsy i Lipa do parafii kijskiej potwierdza Liber beneficiorum Jana Długosza (DLB t. I, s. 475), natomiast wydzielenie Jawora z parafii w Kijach w roku 1331 potwierdza 
łby posłużyć do postawienia tezy, że dziesięciny z Kars, Lipy i Jawora zostały nadane kanonii brzechowskiej przy okazji utworzenia prebendy żydowskiej w roku 1213 r. Takiemu rozumowaniu zdaje się sprzeciwiać lektura dokumentu Wincentego Kadłubka. Z jego treści wynika, że w 1213 r. biskup przeniósł z Kijów do kapituly kieleckiej jedną z prebend wraz z jej uposażeniem. Fakt przeniesienia prebendy wraz $z$ uposażeniem zdaje się sugerować, że odbyło się to bez wydzielania z jej zasobu jakichkolwiek dochodów. Co więcej doszło do sytuacji odwrotnej, tj. prebenda przenoszona do Kielc została dodatkowo powiększona o dziesięciny z wsi Podłęż $\mathrm{e}^{38}$.

W tej sytuacji powraca problem zadośćuczynienia za niedoszłe do skutku nadanie kanonii brzechowskiej dziesięciny z Ostrowa. Wydaje się, że taką rekompensatą były dziesięciny z wsi Jawor, Karsy i Lipa. Wniosek taki potwierdza porównanie wartości dziesięciny z Ostrowa ${ }^{39}$ oraz Kars, Lipy i Jawora. W 1529 r. dziesięciny z pól kmiecych w Ostrowie przynosiły biskupowi krakowskiemu 5 grzywien ${ }^{40}$, podczas gdy łączna suma opłat z Kars, Lipy i Jawora opiewała na 6 grzywien ${ }^{41}$ a zatem różniły się $\mathrm{w}$ niewielkim stopniu. Trudno powiedzieć dlaczego dziesięcina z Ostrowa nie została przejęta przez kanonika. Zarówno Ostrów jak i Obice, Łukowa, Karsy, Lipa oraz Jawor leżą stosunkowo blisko siebie (patrz mapa $\mathrm{nr}$ 1) co sprawia, że powodem nie mogły być trudności związane z zarządzaniem zbyt rozproszonymi dochodami.

Wracając jednak do zasadniczego problemu można przypuszczać, że przed 1359r.kanoniabrzechowska posiadałauposażenie składającesięzdochodów zBrzechowa, Kielc i Tarczku. Oznacza to, że w 2/3 uposażenie to było wspólne ze scholasterią kielecką (patrz tabela nr 4).

Tabela nr 4: Przypuszczalne elementy składowe uposażenia scholasterii i kanonii brzechowskiej w Kielcach do roku 1359/1364.

\begin{tabular}{|c|c|c|c|c|}
\hline \multirow{2}{*}{ L.p. } & Nazwa wsi & Parafia & W ramach uposażenia \\
\cline { 3 - 5 } & Zagórze & Kielce & + & $\begin{array}{c}\text { kanonii } \\
\text { brzechowskiej }\end{array}$ \\
\hline 1. & Złota & $\begin{array}{c}\text { św. Piotra w Sandomie- } \\
\text { rzu }\end{array}$ & + & - \\
\hline 2. & & & + \\
\hline
\end{tabular}

dokument erekcyjny parafii w Chomentowie. W dokumencie tym wieś Jawor została wymieniona pod nazwą Wola (J. Wiśniewski, Historyczny opis kościołów, miast, zabytków i pamiątek w jędrzejowskiem, Marjówka 1930, s. 419-421 a także E. Wiśniowski, Rozwój sieci parafialnej w prepozyturze wiślickiej w średniowieczu, Rozprawy zespołu badań nad polskim średniowieczem Uniwersytetu Warszawskiego i Politechniki Warszawskiej, cz. III, Warszawa 1965, s. 86, przypis nr 2). O tym, że pod nazwą Wola ukrywała się wieś Jawor informuje Jan Długosz (DLB t. I, s. 393 patrz też Wiśniowski, Rozwój sieci parafialnej, s. 123).

${ }^{38}$ KDKK t. I, nr 9, s. 14.

${ }^{39} \mathrm{Z}$ wielu wsi o tej nazwie w grę wchodzi chyba wyłącznie Ostrów z parafii Brzeziny w okolicy Chęcin, który w 1529 r. należał do klucza kieleckiego dóbr biskupich (LR 1529, s. 24).

${ }^{40}$ LR 1529, s. 24.

${ }^{41}$ LR 1529, s. 400. 


\begin{tabular}{|c|c|c|c|c|}
\hline 3. & Wierzbie & Drugnia & + & - \\
\hline 4. & Kielce & Kielce & + & + \\
\hline 5. & Tarczek & Tarczek & + & + \\
\hline 6. & Brzechów & Daleszyce & - & + \\
\hline
\end{tabular}

Ostatecznie zatem w zamian za dochody z Kielc i Tarczku scholasteria otrzymała dziesięciny w Umianowicach, natomiast kanonia brzechowska we wsiach Obice i Łukowa oraz najpewniej Jawor, Karsy i Lipa. Dodatkowym potwierdzeniem takiego rozumowania (a jeśli nie, to wyjątkowym zbiegiem okoliczności) jest to, że dziesięcina z Umianowic w czasach Jana Długosza dawała scholastykowi 20 grzywien, czyli dokładnie tyle ile do kiesy kanonika prebendy brzechowskiej trafiało z Obic, Jawora, Kars, Lipy i Łukowej ${ }^{42}$.

Wydaje się, że tak ścisłe podobieństwo elementów uposażeniowych wskazanych wyżej prałatur i kanonii nie było sprawą przypadku. Jest zatem wielce prawdopodobne, że wszystkie te prebendy utworzono jednocześnie albo też jedne z drugich wydzielono na jakimś etapie rozwoju kapituły. Ponieważ nie ulega wątpliwości, że scholasteria i kustodia istniały już w roku 1229, zatem kanonie pierzchnicka i brzechowska albo powstały wcześniej (równocześnie z dwiema wspomnianymi prałaturami?), albo też wydzieliły się z nich dopiero po roku 1229. Aby przybliżyć się do rozstrzygnięcia tej kwestii należy przyjrzeć się uposażeniu pozostałych kanonii. Bez trudu można dostrzec, że trzy z nich tj. żydowska, szydłówecka i szewieńska wykazują daleko idące podobieństwa. Wszystkie posiadają fundum w postaci nadania ziemskiego oraz dziesięciny płynące ze zwartego obszaru. Zacieśniając pole obserwacji można zauważyć, że w przypadku kanonii żydowskiej i szydłóweckiej fundum stanowiła cała wieś a okręg dziesięcinny obejmował pokaźną liczbę 9-10 wsi położonych wokół Kij[ów] (w przypadku kanonii żydowskiej) ${ }^{43}$ i Chęcin (w przypadku kanonii szydłóweckiej) ${ }^{44}$. Kanonia szewieńska z 1 łanem w ramach fundum i dziesięcinami z jedynie 5 wsi położo-

${ }^{42}$ DLB t. I, s. 450 i 474-475. W 1529 r. podobieństwo w wysokości dochodu już nie występowało, bowiem scholastyk otrzymywał z Umianowic jedynie 10 grz. a kanonik z Obic, Jawora, Kars, Lipy i Łukowej 16,5 grz. - patrz LR 1529, s. 382 i 400.

${ }^{43}$ Fundum stanowiła wieś Żydówek, natomiast dziesięciny kanonia czerpała z 10 wsi. Były to: Stawiany, Gartatowice, Sadowye (wieś poświadczona w ramach uposażenia prebendy żydowskiej do 1529 r., później wchłonięta przez Gartatowice - patrz D. Olszewski, E. Wiśniowski, Parafia Kije. Zarys dziejów, Kielce 1993, s. 23), Szarbków, Chruścice, Wola Żydowska, Żydów Wielki albo Rycerski, Szczypiec, Brzeście i Podłęże. Wszystkie wsie należały bądź do parafii Kije, bądź do sąsiedniej parafii w Pińczowie (DLB t. I, s. 458-461).

${ }^{44}$ Fundum stanowiła wieś Szydłówek, przy czym kanonik nie czerpał z niej w zasadzie żadnych dochodów. O tym, że wieś zanim zaczęła uiszczać świadczenia na rzecz wikariusza, stanowiła uposażenie kanonii świadczy to, że stanowiła własność kanonika. Podstawę funkcjonowania kanonii stanowiły dziesięciny z miejscowości: Chęciny, Góry, Szewce, Bolechowice, Radkowice, Wola Murowana, Młodzawy Wielkie, Młodzawy Małe oraz Zalupa alias Wolya (DLB t. I, s. 465-468). Większość miejscowości należała do parafii Chęciny, jedynie Szydłówek znajdował się w parafii Kielce, natomiast Młodzawy Wielkie i Małe oraz Zalupa alias Wolya (zgodnie z ustaleniami E. Wiśniowskiego pod nazwą tą kryje się wieś Bugaj - Wiśniowski, Rozwój sieci parafialnej, s. 139) podlegały opiece plebana w Młodzawach Małych. 
nych w okolicach Szewnej5 wydaje się w tej sytuacji stanowić niepełną „kopię” dwóch wcześniej omówionych kanonii. W tej sytuacji wydaje się, że powstanie kanonii szydłóweckiej mogło nastąpić równocześnie z utworzeniem kanonii żydowskiej, natomiast kanonia szewieńska powstała później ${ }^{46}$.

W tej sytuacji trudno o konkluzję. Najłatwiejszym - pytanie tylko czy najbliższym prawdzie - wnioskiem byłoby uznanie, że w 1229 r. obok kanonii żydowskiej istniały także kanonie pierzchnicka i brzechowska a ich powstanie odbyło się poprzez wydzielenie z kustodii i scholasterii. Przy takim rozwiązaniu trudno jednak wytłumaczyć dlaczego kanonia szydłówecka powstała dopiero po roku 1229, skoro pod względem uposażenia była niemal kopią kanonii żydowskiej a ponadto posiadała fundum, które $\mathrm{z}$ racji położenia mogło być niegdyś elementem uposażenia parafii św. Wojciecha. W tej sytuacji czasu jej powstania należałoby doszukiwać we wcześniejszym okresie. Dodatkowo wątpliwości pogłębia zapiska Jana Długosza mówiąca o tym, że także uposażenie dziesięcinne prebendy szydłóweckiej leżące w okolicach Chęcin należało pierwotnie do parafii św. Wojciecha ${ }^{47}$. Oznaczałoby to, że prebendy szydłóweckiej należy szukać wśród najwcześniej wydzielonych prebend.

Innym rozwiązaniem byłoby przyjęcie, że „bliźniacze” kanonie żydowska i szydłówecka powstały bądź równocześnie, bądź w niewielkim odstępie czasu. $\mathrm{W}$ takim razie to zasiadający na nich kanonicy zostali wymienieni w $1229 \mathrm{r}$. Kto jednak był trzecim kanonikiem wymienionym w tym roku? Przeciw kanonikowi kanonii szewieńskiej przemawia to, że parafię szewieńską zgodnie odnosi się do pierwszej połowy XIII w. przez co kanonia utworzona w oparciu o jej dochody datowana jest dopiero na połowę XIII w. lub niewiele wcześniej. Może zatem trzecim kanonikiem był posiadacz prebendy pierzchnickiej lub brzechowskiej? Nie musiały one przecież powstawać równocześnie a przez to jedna z nich mogła zostać poświadczona w 1229 r., podczas gdy druga została utworzona dopiero później. Możliwe także, że obie omawiane kanonie już wtedy istniały a dokument z 1229 r. nie wymienił jednej z czterech istniejących w tym czasie kanonii a co za tym idzie nie poświadcza pełnego składu kapituły.

Można wreszcie postawić hipotezę, która będzie godziła zaprezentowane wyżej teorie. Wracając raz jeszcze do dokumentu z 18 I 1229 r. warto przypomnieć, że wymienia on kolejno 3 prałatów, 3 kanoników, przełożonego szkoły kolegiackiej i 7 wikariuszy. Liczba wikariuszy stała się podstawą do twierdzenia, że kapituła kielecka w $1229 \mathrm{r}$. składała się w tym czasie z 4 prałatur (3 wymienionych w dokumencie i nie wymienionej a niewątpliwie istniejącej prepozytury) i 3 kanonii. Można jednak zaryzykować twierdzenie, że dokument biskupa Iwona wymie-

\footnotetext{
${ }^{45}$ Fundum stanowił jeden łan (należący niegdyś do plebana w Szewnej) i zagrodnik w Szewnej, natomiast dziesięciny kanonia czerpała z wsi Gromadzice, Czerwona Góra, Ruszków, Sadowie i Stryczowice. Wszystkie wsie należały do sąsiadujących ze sobą parafii w Szewnej, Ruszkowie i Maninie (DLB t. I, s. 462-464).

${ }^{46}$ Przypuszczenie o późniejszym powstaniu kanonii szewieńskiej zgadza się z wnioskami do jakich doszedł w tej sprawie J. Szymański, który czas jej utworzenia odnosi do połowy XIII w. patrz wyżej.

${ }^{47}$ DLB t. I, s. 464-465.
} 
nia w rzeczywistości 8 wikariuszy. Ważna będzie tu analogia zaczerpnięta z kapituły wiślickiej. W Liber beneficiorum Jana Długosza, przy opisie wicescholasterii wiślickiej, autor zamieścił wzmiankę mówiącą o tym, że do XV w. scholasteria nie posiadała wikariusza. Jego funkcję pełnił przełożony szkoły kolegiackiej (podkreślenie moje). Dopiero scholastyk Piotr s. Stanisława z Fałkowa w porozumieniu z kapitułą ustanowił wicescholastyka do uczestnictwa w oficjum podczas gdy przełożony szkoły miał odtąd zajmować się wyłącznie obowiązkami szkolny$\mathrm{mi}^{48}$. Jeśli w kapitule wiślickiej przełożony szkoły kolegiackiej mógł pełnić także funkcję wicescholastyka, to nie można wykluczyć, że w Kielcach było podobnie. W tej sytuacji dokument z 1229 r. poświadczałby istnienie wszystkich znanych i później prałatur oraz czterech(!) kanonii posiadających prawnie wydzielone prebendy: pierzchnickiej i brzechowskiej wyłonionych odpowiednio z kustodii i scholasterii oraz szydłóweckiej i żydowskiej. Tu po raz kolejny pojawia się analogia z kapitułą wiślicką, której skład stanowiło także 4 prałatów i 4 kanoników. Możliwe zatem, że obie kapituły w początkach XIII w. przeszły podobną reorganizację polegającą na utworzeniu korporacji liczących po 8 członków posiadających prawnie wydzielone prebendy ${ }^{49}$. Przyjęcie takiego scenariusza wydarzeń zdaje się sugerować, że wszystkie wymienione wyżej prebendy kieleckie zostały utworzone jednocześnie. Ponieważ czas powstania prebendy żydowskiej nie ulega wątpliwości, zyskujemy dodatkową przesłankę wskazującą na biskupa Wincentego Kadłubka jako inicjatora gruntownej reorganizacji kapituły kieleckiej. Co więcej spostrzeżenia J. Wroniszewskiego na temat okoliczności powstania kanonii żydowskiej ${ }^{50}$ oraz fakt uposażenia kanonii szydłóweckiej dziesięcinami z dóbr książęcych leżących na terenie arcybiskupstwa gnieźnieńskiego wyraźnie wskazuje, że do dzieła reformy kieleckiego środowiska kanonickiego udało się biskupowi Wincentemu zaangażować księcia Leszka Białego, arcybiskupa gnieźnieńskiego Henryka Kietlicza a także członków rodu Powałów.

Czas ufundowania kanonii szewieńskiej należy w tej sytuacji odnieść do połowy XIII w. - a w każdym razie do czasu po 1229 r.

Znacznie łatwiejszy do ustalenia jest czas powstania ostatniej z kanonii kieleckich. Była to kanonia zwana sieradowską. Jej utworzenie da się względnie dokładnie datować na 2 ćwierć XIV w. Wniosek taki oparty jest na analizie XIVwiecznych spisów dziesięciny papieskiej. W pierwszych dwóch spisach z lat 1326 i 1327 w kapitule kieleckiej odnotowano jedynie 5 kanonii. Szósta pojawiła się dopiero w wykazie z 1350/1351 r. Była to kanonia o najniższym uposażeniu oszacowanym na 2,5 grzywny. Ponieważ zasiadał na niej Jan s. Sędka, który na kanonii zastąpił Tomasza z Włostowa ${ }^{51}$ nie mogła ona powstać tuż przed $1350 \mathrm{r}$. Z drugiej strony brak tej kanonii w wykazach z lat 1326 i 1327 nakazuje przyjąć, że

${ }^{48}$ DLB t. I, s. 417.

${ }^{49}$ Niestety skład kapituły wiślickiej jest znany dopiero z XIV w. a zatem nie wiadomo czy już w XIII w. składała się z 8 godności (Poniewozik, Prałaci i kanonicy wiśliccy, s. 13-14).

${ }^{50} \mathrm{~J}$. Wroniszewski, O początkach kościoła $w$ Kijach, w: Cursus mille annorum. Prace ofiarowane Profesorowi Eugeniuszowi Wiśniowskiemu, „Roczniki Humanistyczne”, 48 (2000) z. 2 - zeszyt specjalny, s. 627.

${ }^{51}$ ACA, t. II, s. 370, 384, 439. 
kanonia ta powstała w latach 30-tych lub 40-tych XIV w. Utożsamienie tej kanonii ze znaną z XV w. kanonią sieradowicką opiera się na analizie uposażenia. Kanonia odnotowana po raz pierwszy w 1350/1351 r. osiągała wyraźnie niższe dochody od pozostałych kanonii kapituły kieleckiej. W Liber beneficiorum Jana Długosza i Liber retaxationum z 1529 r. kanonią o najniższych dochodach była właśnie kanonia sieradowska ${ }^{52}$. Jej słabość wynikała $\mathrm{z}$ oparcia dochodów na dziesięcinach z zaledwie $2 \mathrm{wsi}^{53}$.

Zdaniem Jana Długosza kanonia ta została uposażona dochodami należącymi wcześniej do plebana w Świętomarzy. Jest to możliwe, bowiem w pierwszej połowie XIV w. obie wsie uiszczające dziesięciny na rzecz prebendy sieradowickiej należały najpewniej do parafii w Tarczku ${ }^{54}$ a ta wyłoniła się w początkach XIII w. z parafii w Świętomarzy. W tej sytuacji wydaje się wielce prawdopodobne, że jeszcze w XIV w. pleban w Świętomarzy mógł pobierać dziesięciny z wsi leżących w niezbyt dużej odległości a co więcej niegdyś podlegających jego opiece duszpasterskiej. Nie sposób jednak nie zauważyć, że teren ten stanowił podstawę uposażenia prepozytury kieleckiej ${ }^{55}$. Możliwe zatem, że kanonia sieradowicka powstała kosztem okrojenia dochodów prepozyta. Byłaby to sytuacja analogiczna do sposobu utworzenia kanonii pierzchnickiej i brzechowskiej, jest jednak wątpliwe aby kanonia sieradowicka powstała równocześnie z nimi. Wskazuje na to przede wszystkim znacznie niższe uposażenie.

Wszystkie wyżej zaprezentowane rozważania w znaczącej części są próbą nieco innego niż zaprezentowana przez J. Szymańskiego ujęcia dziejów kształtowania się składu kapituły kieleckiej. Odrębnego potraktowania wymagają wnioski do jakich doszedł S. Trawkowski.

Przypomnę, że problematykę kształtowania się składu osobowego kapituły

${ }^{52}$ DLB t. I, s. 468-469 i LR 1529, s. 375.

${ }^{53}$ Tamże. W innym miejscu skłaniałem się ku przypuszczeniu, że kanonia sieradowska tożsama jest z kanonią kielecką, która w XIV w. uzyskiwała dochód szacowany na 5 grz. (Poniewozik, Uposażenie prałatur i kanonii średniowiecznych kapitut kolegiackich $w$ diecezji krakowskiej, [w dru$\mathrm{ku}]$ ). Takie przypuszczenie opierało się na porównaniu informacji podanych przez Liber beneficiorum i Liber retaxationum z przekazem XVI-wiecznych rejestrów poborowych duchowieństwa diecezji krakowskiej, które za podstawę do szacowania podatków przyjmowały XIV-wieczne taksy, ale przy określaniu prebend kanonickich posługiwały się nazwami urobionymi od fundum. Taki sposób postępowania może jednak w niektórych przypadkach prowadzić na manowce, czego przykładem może być kanonia żydowska - patrz wyżej, przypis nr 26.

${ }^{54}$ Co prawda obie wsie uposażeniowe należały w czasach Jana Długosza do dwóch różnych, jednak sąsiadujących ze sobą parafii: Sieradowice do parafii w Bodzentynie a Śniadka do parafii w Tarczku (DLB t. I, s. 438, 468-469). Ponadto powstała dopiero w 1355 r. parafia w Bodzentynie wyłoniła się z terenu parafii w Tarczku i Dąbrowie (ZDM t. IV, nr 948, s. 98). Źródło nie podaje wcześniejszej przynależności parafialnej wsi Sieradowice jednak z racji położenia należała ona zapewne do parafii tarskiej.

${ }^{55}$ Dochody prepozyta kieleckiego pochodziły z miejscowości znacznie oddalonych od Kielc a skoncentrowanych przede wszystkim wokół Świętomarzy oraz Pawłowa i - w nieco mniejszym stopniu - Waśniowa (DLB t. I, s. 437-442 i LR 1529 s. 376-377). Co więcej Jan Długosz wprost stwierdził, że prepozytura została ufundowana na dochodach odebranych plebanowi w Świętomarzy (DLB t. I, s. 436). Nie wiadomo jednak, czy Jan Długosz miał na ten temat jakieś informacje źródłowe, czy też wnioski swe opierał na obserwacji stosunków uposażeniowych z drugiej połowy XV w. 
kieleckiej widział on zupełnie inaczej. Należy jednak pamiętać, że głównym zagadnieniem na jakim autor ten się skupił była sprawa funkcjonowania prepozytury tarskiej, a zatem uwagi na temat kapituły kieleckiej czynił na marginesie głównego wątku swoich rozważań. To w pełni tłumaczy pobieżność potraktowania początków kapituły kieleckiej. Rozważania na temat prepozytury tarskiej doprowadziły S. Trawkowskiego do stwierdzenia, że kapituła kielecka w przejściowej formie ustrojowej z prawnie wydzieloną i niezwykle bogatą prebendą prepozyta i wspólnym majątkiem pozostałych członków przetrwała do połowy XIII w. Wydzielenie pozostałych prebend prałackich i kanonickich nastąpiło zdaniem tego autora dopiero po likwidacji prepozytury tarskiej. Wtedy to majątek prepozyta kieleckiego posłużył do ufundowania prebend pozostałych członków kapituły kieleckiej, natomiast pozbawiona dotychczasowego uposażenia prepozytura kielecka otrzymała dochody zlikwidowanej prepozytury tarskiej. Tej szeroko zakrojonej reformy mógł dokonać wyłącznie człowiek cieszący się znaczącym autorytetem. Taką osobę S. Trawkowski widzi w biskupie krakowskim Prandocie.

Całość rozumowania S. Trawkowskiego opierała się na założeniu, że pojedyncza wzmianka źródłowa wspominająca prepozyta w Tarczku oznacza istnienie nie tylko prepozytury w tym ośrodku, ale i grupy kanonickiej, w pewnym sensie konkurencyjnej wobec kapituły kieleckiej. Takie założenie nie wydaje się jednak uprawnione. Co prawda rozważania na ten temat tylko częściowo wiążą się w treścią mego artykułu, ponieważ jednak stanowią one dla S. Trawkowskiego punkt wyjścia do wnioskowania o czasie powstania prebend w kolegiacie kieleckiej nie mogę ich pominąć. Wracając zatem do istnienia bądź nie istnienia kapituły tarskiej warto skupić się nad kilkoma rzeczami. Przede wszystkim S. Trawkowski przyjmuje w sposób bezdyskusyjny, że użyty w 1228 r. termin prepositus de $\operatorname{Tarsc}^{56}$, oznacza prepozyta z Tarczku ${ }^{57}$, a zatem używając terminologii stosowanej jeszcze w pierwszej połowie XVI w. - w Tarczku Nowym ${ }^{58}$. Ponadto autor ten zdaje się zgadzać, że znacząca rola Tarczku zaczyna się w pierwszej połowie XIII w. Świadczy o tym zarówno czas budowy późnoromańskiego kościoła św. Idziego $^{59}$ jak również przeniesienie tutaj ośrodka targowego ze Świętomarzy zwanej

${ }^{56} \mathrm{KDM}$ t. I, nr 11, s. 17.

${ }^{57}$ S. Trawkowski, Zagadka prepozytury tarskiej, w: Opuscula mediaevistica. Studia nad historia społeczna Polski wczesnopiastowskiej, Warszawa 2005, s. 134. W tym względzie panuje jednak wyjątkowa zgodność wśród historyków. Praktycznie wszyscy zajmujący się tym problemem łączyli wzmiankę z 1228 r. z Tarczkiem nie rozważając nawet innej możliwości - patrz T. Lalik, Stare miasto $w$ Łęczycy. Przemiany w okresie poprzedzajacym lokację-schyłek XII i początek XIII w., „Kwartalnik Historii Kultury Materialnej”, 4 (1956) s. 637; Szymański, Kanonicy świeccy, s. 312. Całkowitej pewności w tym względzie nie miała natomiast B. Rzewuska-Kurzeja, choć skłaniała się ku temu, by prepozyta tarskiego wiązać z Tarczkiem Nowym - B. Rzewuska-Kurzeja, Rozwój sieci parafialnej w prepozyturze kieleckiej w średniowieczu, „Nasza Przeszłość”, 59 (1983) s. 85.

${ }^{58}$ Pod taką nazwą (Tharzek Nova) Tarczek wystąpił w Liber retaxationum z 1529 r. - Księga dochodów beneficjów diecezji krakowskiej z roku 1529 (tzw. Liber retaxationum), wyd. Z. Leszczyńska-Skrętowa, Wrocław 1968, s. 372

${ }^{59}$ Przyznaje to sam Trawkowski - Zagadka prepozytury tarskiej, s. 135. Nowszą literaturę dotyczącą datacji kościoła św. Idziego przytacza Z. Brzeziński, Fundacja kościoła w Tarczku a rozwój kultu św. Idziego w Polsce średniowiecznej, w: Bodzentyn. Z dziejów miasta w XII-XX wieku, red. K. 
też Starym Tarczkiem ${ }^{60}$. Mimo to S. Trawkowski upatruje w Tarczku siedziby dla prepozyta i grupy kanonickiej w okresie poprzedzającym wzrost jego roli. Wątpliwości co do możliwości funkcjonowania grupy kanonickiej w Tarczku podnosił nie tak dawno Z. Brzeziński. Bazując na analizie rozprzestrzeniania się kultu św. Idziego a ponadto przyglądając się wiarygodności przekazów dotyczących czasu wzniesienia świątyni tarskiej doszedł on do przekonujących wniosków negujących możliwość funkcjonowania kapituły w Tarczku ${ }^{6}$. Wydaje się ponadto, że zaproponowane przez tego autora wytłumaczenie pojawienia się w źródłach postaci prepozyta tarskiego zasługuje ze wszech miar na uwagę ${ }^{62}$. Należy ponadto pamiętać, że do początków XIII w. wiodącym ośrodkiem w tym rejonie kielecczyzny była Świętomarza. W tej to miejscowości powstał bogato uposażony i odnoszony do XII a nawet końca XI w. kościół p.w. NMP ${ }^{63}$ i tu wcześniej znajdował się ośrodek targowy, przeniesiony następnie do Tarczku - stąd i inna, starsza nazwa Świętomarzy, która pierwotnie brzmiała Tarczek a od początku XIII w. - Stary Tarczek. W tej sytuacji przyjmując założenie S. Trawkowskiego, że w Tarczku [Nowym] grupa kanonicka powstała jeszcze w XII w., pojawia się pytanie po co tworzono kapitułę w jeszcze wówczas mało znaczącym ośrodku (o ile w ogóle istniejącym), skoro kilka kilometrów dalej znajdował się silny ośrodek handlowy posiadający dobrze uposażony kościół? Wątpliwości pogłębia fakt niskiego uposażenia kościoła w Nowym Tarczku, który ponadto - jak się wydaje - początkowo podlegał parafii w Tarczku Starym. Fakty te doskonale znane S. Trawkowskie$\mathrm{mu}^{64}$ nie wpłynęły na jego przekonanie co do czasu powstania kapituły w Tarczku a nawet poskutkowały postulatem poszukiwania śladów wcześniejszej świątyni,

Bracha, Kielce 1998, s. 35. Na szczególną uwagę zasługuje teza K. Białoskórskiej wiążącej powstanie kościoła w Tarczku z fundacjami cysterskimi w Małopolsce (Wąchock). Autorka wskazuje nawet cysterski warsztat brata Simona jako prawdopodobnego wykonawcę budowli co zawężałoby czas powstania kościoła św. Idziego do lat 1217-1239 (K. Białoskórska, Klasztory a zagadnienia ksztaltowania się lokalnych polskich środowisk i tradycji artystycznych $w$ XIII stuleciu, [w:] Klasztor w społeczeństwie średniowiecznym i nowożytnym, pod red. M. Derwicha i A. Pobóg-Lenartowicz, Opole-Wrocław 1996, s. 318 i 327).

${ }^{60} \mathrm{~S}$. Trawkowski za T. Lalikiem przyjmuje, że translacja ośrodka targowego wiązała się z czasem uzyskania przez biskupa Iwona Odrowąża zgody od księcia na utworzenie w Tarczku osady targowej dla kolonistów niemieckich - patrz T. Lalik, Stare miasto $w$ Łęczycy. Przemiany w okresie poprzedzajacym lokacje - schytek XII i poczatek XIII w., „Kwartalnik Historii Kultury Materialnej”, 4 (1956) s. 636-637 i Trawkowski, Zagadka prepozytury tarskiej, s. 134-135.

${ }^{61}$ Z. Brzeziński, Fundacja kościoła w Tarczku a rozwój kultu św. Idziego w Polsce średniowiecznej, w: Bodzentyn. Z dziejów miasta w XII-XX wieku, red. K. Bracha, Kielce 1998, s. 33-38.

${ }^{62} \mathrm{Z}$. Brzeziński uznaje, że biskup Iwon Odrowąż wraz z utworzeniem nowego ośrodka gospodarczego dla dóbr biskupich na kielecczyźnie podjął pod koniec swego pontyfikatu próbę utworzenia prepozytury w Tarczku. Próba ta nie powiodła się w związku z rychłą śmiercią Iwona a jego następca nie kontynuował dzieła poprzednika - patrz tamże, s. 37-38.

${ }^{63}$ B. Rzewuska-Kurzeja, Rozwój sieci parafialnej w prepozyturze kieleckiej w średniowieczu, „Nasza Przeszłość”, 59 (1983) s. 82-85.

${ }^{64} \mathrm{O}$ słabym uposażeniu i podległości parafialnej kościoła z Nowego Tarczku względem parafii z Tarczku Starego pisze sam Trawkowski - Zagadka prepozytury tarskiej, s. 135-136. 
w której kapituła ta miałaby mieć swoją siedzibę w XII w. ${ }^{65}$ Rozważania na temat istnienia kapituły w Tarczku S. Trawkowski uzupełnia tezami na temat dziejów prepozytury i dziekanii w korporacji kieleckiej. Ponieważ w świetle Długoszowej Liber beneficiorum dochody prepozyta kieleckiego stanowiły wpływy z miejscowości położonych w okolicach Świętomarzy S. Trawkowski doszedł do wniosku, że pierwotnie należały one nie do prepozyta kieleckiego a prepozyta tarskiego. Dodatkowym potwierdzeniem tej tezy miałoby być to, że dochody prepozyta kieleckiego znane $\mathrm{z}$ drugiej połowy XV w. miały prawie czterokrotnie ustępować wartością zsumowanym dochodom tych członków kapituły kieleckiej, którzy uposażeni byli na dochodach dawnego kościoła św. Wojciecha. Ponieważ w przypadku kapituł uposażenie prepozyta - jako wyłonione najwcześniej - najczęściej było znacząco większe niż dochody pozostałych członków kapituły, przeto sytuacja panująca w kapitule kieleckiej w XV w. nie odpowiada zdaniem S. Trawkowskiego stosunkom wcześniejszym. Ponadto cytowanego autora dziwi brak w dochodach prepozyta kieleckiego wpływów pochodzących z uposażenia kościoła św. Wojciecha, przy zachowaniu jego związków z funkcjami parafialnymi, co przejawiało się w jego uprawnieniach do poboru świętopietrza. W dalszej kolejności S. Trawkowski dochodzi zatem do wniosku, że pierwotne uposażenie prepozyta musiało być oparte na dochodach kościoła św. Wojciecha a ponadto było znacząco większe. Dopiero dzięki inicjatywie cieszącego się powszechnym autorytetem biskupa Prandoty dawne uposażenie prepozyta kieleckiego zostało rozparcelowane pomiędzy pozostałych członków kapituły kieleckiej. „Ograbiona” w ten sposób prepozytura kielecka uposażona została natomiast dochodami likwidowanej właśnie prepozytury tarskiej. Co więcej równocześnie wydzielone zostało uposażenie dziekana kieleckiego oparte na dochodach płynących z miejscowości rozlokowanych wokół Radomia, przy czym uposażenie to było znacząco wyższe od dotychczasowego ${ }^{66}$.

${ }^{65}$ Wydaje się, że o ile w ogóle kapituła tarska miałaby istnieć to bardziej prawdopodobnie brzmiałaby w tej sytuacji teza łącząca tę hipotetyczną grupę kanonicką z Tarczkiem Starym, czyli Świętomarzą.

Należy bowiem pamiętać, że jeszcze w XIV w. używano nazwy Stary Tarczek zamiennie w stosunku do nazwy Świętomarza. Nazwa Stary Tarczek (Antiquotarzek, Antiquo Tarzek, Antiquo Tarzecz, Antiqua Tarsek) pojawia się bardzo często m. in. w spisach dziesięciny papieskiej i świętopietrza (ACA t. I, s. 168, 243, 313, 388, t. II, s. 176, 177, 179, 184, 186, 190, 199, 208, 218, 227, 236, $245,254,263,270,278,286,293,300,370-371,403,419$, t. III, s. 18, 38) podczas gdy równolegle wymieniany Tarczek występuje pod nazwą współczesną (Tarzek-ACA t. I, s. 168, 243, 313, 388), bądź nawet częściej notowany jest jako Nowy Tarczek (Novo Tarzek, Nova Tarzek, Novo TarsekACA t. II, s. 199, 208, 218, 227, 236, 245, 254, 263, 270, 278, 286, 293, 403, 419, t. III, s. 18, 37). Taka forma zapisu nazw obu miejscowości sugeruje, że jeszcze w XIV w. nazwa Świętomarza była rzadko stosowana i ustępowała miejsca nazwie starej. Dlatego w celu odróżnienia obu miejscowości jednej dodawano określenie „Stary” drugiej zaś „Nowy” (nazwa Sancta Maria pojawiła się zaledwie dwukrotnie i w obu wypadkach w wersji Sancta Maria seu Antiquo Tarzek co jeszcze dobitniej wskazuje na większą popularność nazwy starej-ACA t. I, s. 168, 243).

${ }^{66}$ Trawkowski, Zagadka prepozytury tarskiej..., s. 137-143. O tym, że majątek prepozyta kieleckiego rzeczywiście pochodził z okolic Świętomarzy patrz przypis nr 55, natomiast dochody dziekana obejmowały dziesięciny $\mathrm{z}$ wsi rozlokowanych w przeważającej większości na terenie parafii 
Ten sugestywny obraz przedstawiony przez S. Trawkowskiego w świetle wyżej zaprezentowanych rozważań nie jest możliwy do przyjęcia. Już choćby to, że kanonia żydowska ufundowana w 1213 r. zachowała swoje uposażenie do drugiej połowy XV w. ${ }^{67}$ stawia pod znakiem zapytania główne tezy S. Trawkowskiego. Dlaczego bowiem szeroko zakrojona reforma kapituły kieleckiej polegająca na odbieraniu członkom kapituły dotychczasowego uposażenia i ustalaniu nowego miałaby nie objąć kanonii żydowskiej, która w pełni ukształtowaną prebendę posiadała już od 1213 r.?

Kolejną wątpliwość budzi rzekome „niedoszacowanie” prepozytury kieleckiej w XV i XVI w. względem prałatur i kanonii uposażonych dochodami dawnego kościoła św. Wojciecha. Odtwarzając jak wyglądało pierwotne uposażenie tych członków kapituły, którzy byli materialnymi „spadkobiercami” kościoła św. Wojciecha, wziął on pod uwagę znane z Długoszowej Liber beneficiorum oraz Liber retaxationum z 1529 r. pełne dochody kustodii, kanonii pierzchnickiej i brzechowskiej oraz pewne elementy uposażenia scholasterii i kanonii szydłóweckiej. Łącznie uwzględnił dochody z następujących miejscowości: Kielce, Mąchocice, Nida, Krajno, Włoszczowice, Cisów, Bardo, Czyżów, Sędziejowice, Kliszów, Złotków, Pierzchnica, Zagórze, Szydłówek, Umianowice, Obice, Łukowa, Jawor, Karsy i Lipa ${ }^{68}$. O ile kryteria doboru użytych do porównania elementów uposażenia można w zasadzie zaakceptować ${ }^{69}$ o tyle z twierdzeniem, że suma tych dochodów miała czterokrotnie przewyższać wpływy uzyskiwane przez prepozy$\operatorname{ta}^{70}$ zgodzić się trudno. Uważna lektura zarówno Liber beneficiorum, jak i Liber retaxationum z 1529 r. przeczy takiemu stwierdzeniu. Dochody prepozyta wynosiły w czasach Jana Długosza 106-112 grz., podczas gdy łączna wartość uposażenia ze wskazanych przez S. Trawkowskiego miejscowości da się ustalić na 142-

w Starym Radomiu, Cerekwi i Jarosławicach (DLB t. I, s. 307-308, 443-447; t. II, s. 514-516; t. III, s. 417; LR 1529 s. 382).

${ }^{67}$ Świadczy o tym samo rozlokowanie uposażenia kanonii żydowskiej w XV w., które wskazuje, że zostało utworzone na bazie dochodów prebendy kijskiej zlikwidowanej w $1213 \mathrm{r}$. a w większym jeszcze stopniu to, że dodana w 1213 r. do uposażenia tworzonej prebendy kieleckiej wieś Podłęże także w czasach Jana Długosza płaciła na rzecz kanonii żydowskiej - patrz DLB t. I, s. 460.

${ }^{68}$ Trawkowski, Zagadka prepozytury tarskiej, s. 139.

${ }^{69}$ Należy jedynie pamiętać, co podkreśla także S. Trawkowski, że dochody z niektórych wskazanych miejscowości stanowiły rekompensatę za utracone elementy pierwotnego uposażenia. Do tej grupy należy zaliczyć niewątpliwie dochody z Umianowic, Pierzchnicy, Obic i Łukowa (o tym, że do uposażenia scholasterii oraz kanonii pierzchnickiej i brzechowskiej trafiły dopiero w XIV w. patrz KDKK t. I, nr 216, s. 273; nr 234, s. 300-301; DLB t. I, s. 450, 470, 474-475) oraz najpewniej także z Włoszczowic, Jawora, Kars i Lipy (najpewniej kustodia i kanonia brzechowska otrzymały je dopiero w XIV w. - patrz L. Poniewozik, Kielecka kapituła kolegiacka w średniowieczu. Wybrane problemy, w druku). E. Wiśniowski ustalając pierwotne uposażenie kościoła św. Wojciecha ostrożnie wskazał na ziemię w Zagórzu, Kielcach i Złotej oraz prawdopodobnie Szydłówku. Nie wykluczył jednak, że oprócz ziemi parafia ta posiadała także dziesięciny z pewnych miejscowości (Wiśniowski E., Początki kościoła i parafii św. Wojciecha w Kielcach, „Nasza Przeszłość”, 57 (1982) s. 163-164).

${ }^{70}$ Trawkowski, Zagadka prepozytury tarskiej, s. 140. 
146 grz. $^{71}$ Jak zatem widać różnica była nieznaczna. Podobnie było także w 1529 r., przy czym w tym przypadku ocenę sytuacji utrudniają nieco pominięcia w opisie niektórych prebend. Mimo to łatwo zauważyć, że dochody prepozyta oszacowane na 117 grz. przy nieco ponad 124 grz. łącznego uposażenia miejscowości wskazanych przez S. Trawkowskiego ${ }^{72}$ nie mogą stanowić podstawy do twierdzenia o jakimkolwiek niedowartościowaniu prepozytury a co za tym idzie upada dodatkowy argument przemawiający za późnym wydzieleniem prebend kieleckich.

Swoją drogą pozycja finansowa prepozyta kieleckiego względem pozostałych członków kapituły kieleckiej znana z drugiej połowy XV w. i roku 1529 była w pełni porównywalna z sytuacją panującą w kapitule sandomierskiej, wiślickiej, św. Floriana i św. Idziego, gdzie uposażenie prałatów stojących na czele korporacji czasem bardzo wyraźnie ustępowało połączonym dochodom pozostałych członków kapituły. Jedynie w przypadku prepozytów skalbmierskiego i u św. Michała oraz dziekana opatowskiego ich uposażenie najczęściej przewyższało wspólne dochody pozostałych członków kapituł (patrz tabela nr 5).

${ }^{71} \mathrm{~W}$ świetle Liber beneficiorum dochody z miejscowości wskazanych przez S. Trawkowskiego a wchodzących w skład uposażenia kustodii, scholasterii oraz kanonii: pierzchnickiej, brzechowskiej i szydłóweckiej kształtowały się następująco: Kielce - 20 grz., Mąchocice - 2 grz., Nida 4 grz., Krajno - 12 grz., Włoszczowice - 13 grz. (wcześniej 15 grz.), Cisów - 5 grz., Bardo - 8 grz., Czyżów - 2 grz., Sędziejowice -8 grz. (wcześniej 10 grz.), Kliszów - 1 grz., Złotków -2 grz., Pierzchnica - 12 grz., Zagórze - 9,5 grz., Szydłówek - 3,5 grz., Umianowice - 20 grz., Obice - 6 grz., Łukowa - 4 grz., Jawor -4 grz., Karsy -3 grz., Lipa -3 grz. (dane na podstawie DLB t. I, s. 449450, 452-456, 465, 468, 470, 472-475). Łącznie daje to 142-146 grz.

W tym samym czasie dochody prepozytury kieleckiej stanowiły następujące wpływy: Grabków - 6 grz. 32 gr., Łomno - 1,5 grz., Świętomarza - brak wartości, Rzepinek - 4 grz. (niegdyś 5 lub 6 grz.), Śniadka -4 grz. (wartość trudna do ustalenia ze względu na niejednoznaczny zapis), Rzepin - 12 grz. (niegdyś 15 grz.), Brzezie - 14 grz., Jadowniki - 8 grz., Dąbrowa - 10 grz., Wieloborowice -2 grz., Trzęsków - 4-8 grz. (wartość trudna do ustalenia ze względu na niejednoznaczny zapis), Pokrzywnica -8 grz., Jabłonna - 4 grz., Dziurów - 2 grz., Śnieżkowice -7 grz., Strupice -5 grz., Kosowice - brak wartości, Witosławice - 2 grz., Sierzawy - 12 grz. (DLB t. I, s. 437-442, 469; t. II, s. 460-461, 485). Po zsumowaniu okaże się, że dochody prepozyta wynosiły 106 grz. 8 gr. -112 grz. $8 \mathrm{gr}$.

${ }^{72} \mathrm{~W} 1529$ r. dochody prepozyta zostały oszacowane na 117 grz. 8 gr., natomiast wsie wymienione przez S. Trawkowskiego odpowiednio: Kielce -25 grz., Mąchocice - brak (wieś wymieniona w uposażeniu wicekustodii, dawała 2 grz. 1 gr.), Nida - 14 grz., Krajno - 15 grz., Włoszczowice 12 grz., Cisów - 1 grz., Bardo - 5 grz., Czyżów - 12 gr., Sędziejowice - 60 gr., Kliszów - 60 gr., Złotków - brak, Pierzchnica - brak, Zagórze - 15 grz., Szydłówek - brak (wieś wymieniona w uposażeniu wikarii szydłóweckiej, dawała 3,5 grz. 4 gr.), Umianowice - 10 grz., Obice - 2,5 grz., Łukowa $-1,5$ grz., Jawor -8 grz., Karsy wraz z Lipą - 4,5 grz. Łącznie dawało to 124 grz. 17 gr. 
Tabela nr 5: Uposażenie prałata stojącego na czele kapituły na tle dochodów pozostałych członków kapituł kolegiackich diecezji krakowskiej w świetle spisów dziesięciny papieskiej z XIV w., Liber beneficiorum Jana Długosza i tzw. Liber retaxationum z 1529 r. $^{73}$

\begin{tabular}{|c|c|c|c|c|}
\hline \multirow{2}{*}{ L.p. } & \multirow{2}{*}{ Nazwa } & \multicolumn{3}{|c|}{ Uposażenie w: } \\
\hline & & XIV w. & XV w. & XVI w. \\
\hline \multicolumn{5}{|c|}{ Kapituła sandomierska } \\
\hline 1. & Prepozyt & 30 grz. & 248 grz. & 227 grz. 2 gr. \\
\hline 2. & $\begin{array}{l}\text { Pozostali prałaci i kanonicy } \\
\text { razem }\end{array}$ & 227 grz. & 1300 grz. 44 gr. & 904 grz. 19 gr. \\
\hline \multicolumn{5}{|c|}{$\begin{array}{ll}\text { Kapituła wiślicka } \\
\end{array}$} \\
\hline 1. & Prepozyt & 76 grz. & 117 grz. 36 gr. & 136 grz. 10 gr. \\
\hline 2. & $\begin{array}{c}\text { Pozostali prałaci i kanonicy } \\
\text { razem }\end{array}$ & 88 grz. & 317 grz. 12 gr. & 242 grz. 5 gr. \\
\hline \multicolumn{5}{|c|}{ Kapituła kielecka } \\
\hline 1. & Prepozyt & 18 grz. & 105 grz. 12 gr. & 117 grz. 8 gr. \\
\hline 2. & $\begin{array}{l}\text { Pozostali prałaci i kanonicy } \\
\text { razem }\end{array}$ & 88,5 grz. & 404 grz. 36 gr. & 365 grz. 15 gr. \\
\hline \multicolumn{5}{|c|}{ Kapituła św. Floriana na Kleparzu } \\
\hline 1. & Prepozyt & 40 grz. & 96 grz. 36 gr. & 122 grz. 32 gr. \\
\hline 2. & $\begin{array}{c}\text { Pozostali prałaci i kanonicy } \\
\text { razem }\end{array}$ & 94,5 grz. & 362 grz. 8 gr. & 128 grz. \\
\hline \multicolumn{5}{|c|}{ Kapitula skalbmierska } \\
\hline 1. & Prepozyt & 80 grz. & 95 grz. 42 gr. & 156 grz. \\
\hline 2. & $\begin{array}{c}\text { Pozostali prałaci i kanonicy } \\
\text { razem }\end{array}$ & 48 grz. 34 gr. & 116 grz. 16 gr. & 134 grz. 30 gr. \\
\hline \multicolumn{5}{|c|}{ Kapituła św. Michała na Wawelu } \\
\hline 1. & Prepozyt & 35 grz. & 132 grz. 24 gr. & 105 grz 44 gr. \\
\hline 2. & $\begin{array}{c}\text { Pozostali prałaci i kanonicy } \\
\text { razem }\end{array}$ & 20 grz. & 47 grz. & 70,5 grz. \\
\hline \multicolumn{5}{|c|}{ Kapitula opatowska } \\
\hline 1. & Dziekan & 10 grz. & 91 grz. 10 gr. & 110 grz. 32 gr. \\
\hline 2. & $\begin{array}{c}\text { Pozostali prałaci i kanonicy } \\
\text { razem }\end{array}$ & 28 grz. 22 gr. & 92 grz. 36 gr. & 42 grz. 10 gr. \\
\hline \multicolumn{5}{|c|}{ Kapituła św. Idziego na Wawelu } \\
\hline 1. & Kustosz & 7 grz. & 12 grz. 24 gr. & 13 grz. 6 gr. \\
\hline 2. & $\begin{array}{c}\text { Pozostali członkowie kapituły } \\
\text { razem }\end{array}$ & 39 grz. & 73 grz. 26 gr. & 45 grz. 40 gr. \\
\hline
\end{tabular}

Podsumowując należy skonstatować, że funkcjonowanie grupy kanonickiej w Tarczku wydaje się bardzo wątpliwe. Także istnienie prepozytury tarskiej najpewniej nie wyszło poza fazę projektu. Równocześnie przypuszczenie jakoby

${ }^{73}$ Dane zawarte $\mathrm{w}$ tabeli $\mathrm{nr} 4$ za Poniewozik, Uposażenie prałatur $i$ kanonii, tabele $\mathrm{nr} 1-8$ [w druku]. 
w kapitule kieleckiej dopiero w połowie XIII w. doszło do powstania prawnie wydzielonych prebend także nie da się utrzymać. Wydaje się natomiast, że ogólne założenie S. Trawkowskiego, co do uposażenia prebend kustosza, scholastyka i kanoników dochodami z pierwotnego majątku kapituły oraz osobnego potraktowania $\mathrm{w}$ tym względzie prepozytury i dziekanii, może być prawdziwe, pod warunkiem wszakże, że wydarzenie to odniesiemy do początków XIII w. Rozmieszczenie uposażenia dwóch najważniejszych prałatur kapituły kieleckiej wskazuje, że ich dochody nie mogły raczej stanowić pierwotnego, sięgającego jeszcze XII w. uposażenia kapituły, która miała przecież powstać na bazie dochodów kościoła św. Wojciecha. Sposób pozyskania uposażenia dla prepozytury i dziekanii przypominał zapewne działania towarzyszące powstaniu kanonii żydowskiej, tj. uzyskane spoza kapituły dochody stały się podstawą do utworzenia nowej kanonii. W przypadku prepozytury i dziekanii, różnica polegała na tym, że pozyskane środki posłużyły nie do utworzenia nowych prałatur a do uposażenia już istnieją$\operatorname{cych}^{74}$. Możliwe także, że zdobycie w początkach XIII w. nowych środków na uposażenie istniejącej od dawna prepozytury kieleckiej oznaczało odebranie jej dotychczasowego uposażenia opartego na dochodach parafii św. Wojciecha i rozdysponowanie go pomiędzy powstające wówczas prebendy pozostałych członków kapituły.

Oznacza to, że początek XIII w. był w dziejach kapituły kieleckiej okresem przełomowym. Z nielicznej grupy kanonickiej posiadającej wspólny majątek oparty na dochodach dawnego kościoła św. Wojciecha a kierowanej przez prepozyta przekształciła się w 8-osobową grupę prałatów i kanoników posiadających wydzielone prebendy.

${ }^{74}$ Fakt że któryś z biskupów krakowskich posłużył się w tym celu dochodami należącymi wcześniej do kościołów parafialnych - czy to podlegających patronatowi biskupiemu, czy też rodów związanych z biskupami krakowskimi - znajduje w pierwszej połowie XIII w. liczne analogie na terenie diecezji krakowskiej. Można tu wskazać choćby przykład uposażenia klasztoru w Mogile m. in. dochodami kościoła w Prandocinie, czy też oddanie nowotworzonemu klasztorowi w Imbramowicach uposażenia kościoła św. Benedykta znajdującego się w tej miejscowości - patrz Diplomata monasterii Clarae Tumbae prope Cracoviam [dalej KMog], wyd. E. Janota, Kraków 1865, nr 2, s. 2-3 oraz KDKK t. I, nr 22, s. 30. 


\title{
CHRONOLOGY OF THE FORMATION OF PREBENDARIES IN THE CHAPTER OF KIELCE
}

\begin{abstract}
Summary
The aim of this article is to present the early days of the formation of the Collegiate Chapter in Kielce. The analysis of the source material indicates that the Chapter of Kielce was founded in the $12^{\text {th }}$ century on the basis of the revenue of the St. Adalbert Church in Kielce. At the beginning all the members of the corporation lead a community life (vita communis), but over time the assets of the Chapter was divided by separating particular prebendaries. This reorganization took place probably at the beginning of the $13^{\text {th }}$ century. Perhaps this event occurred in 1213. In any case it happened before the year 1229. As a result of the reorganization 7 or 8 prebendaries were created. The earliest prebendaries were all prelatures, that is, provostry, custody, decania, scholasteria. Three or four canonic prebendaries were part of the Chapter and it is certain that the canonry, called the Jewish one, created in 1213 was among them. The others are probably the prebendaries of Pierzchnica, Brzechów and Szydłowiec. The late medieval composition of the Chapter comprising 4 prelatures and 6 canons was completed, in time, by the canons called Szewno and Sieradowice. The first one was created in the middle of the $13^{\text {th }}$ century, and the other one between 1327 and 1350 .

As it has been mentioned above, the creation of the Chapter of Kielce was connected with the acquisition of the property of St. Adalbert Church. The income derived from it was, however, too meager to meet the needs of all the prelates and canons. In the light of the late medieval sources it can be assumed that the revenue of the St. Adalbert Church was used to create only 2 prelatures (custodia and scholasteria) and 2 canons (Pierzchnica and Brzechów). The pay for other prebendaries came from other sources. It is assumed that the main founders-if not the only ones-were the Bishops of Kraków.
\end{abstract}

